\title{
Towards a Systematic Understanding on the Challenges of Procuring Artificial Intelligence in the Public Sector
}

\author{
Keegan McBride ${ }^{\mathrm{a}, \mathrm{b}, *}$, Colin van Noordt ${ }^{\mathrm{c}}$, Gianluca Misuraca ${ }^{\mathrm{d}}$, and Gerhard \\ Hammerschmid $^{\mathrm{a}}$
}

${ }^{a}$ Centre for Digital Governance, Hertie School, Berlin, Germany;

${ }^{b}$ Mohammed Bin Rashid School of Government, Dubai, UAE;

${ }^{c}$ Ragnar Nurkse Department of Innovation and Governance, Tallinna Tehnikaülikool,

Tallinn, Estonia;

${ }^{d}$ Danube University Krems, Krems, Austria.

*last_name@hertie-school.org

Word limit: 7825 / 8,000 (references excluded)

\begin{abstract}
There is an increased interest amongst governments and public sector organizations about how to best integrate artificial intelligence into their day-to-day business processes. Yet, a large majority of technical knowhow is concentrated within the private sector, requiring most public sector organizations to rely on public procurement for AI systems. While many governments may have experience with traditional forms of public technological procurement, this paper argues that the public procurement of $\mathrm{AI}$ is different and new insight is needed to understand this differentiation and procure AI better. This paper offers an initial contribution to the public administration and management literature by describing this difference, and identifying the challenges associated with the public procurement of AI. In order to achieve this contribution, the research studied guidelines in four European countries (Estonia, Netherlands, Serbia, and the United Kingdom) to generate insight into the challenges faced, and potential solutions to these challenges, during the public procurement of AI process.
\end{abstract}

Keywords: Artificial intelligence, procurement, public administration, digital government, eGovernment 


\section{Introduction}

Artificial Intelligence (AI) has permeated throughout our society; many individuals come in contact with AI in their day to day lives, whether it is known or not. A large majority of AI developments have been driven traditionally by the private sector, especially larger companies such as Amazon, Google, IBM, and Facebook. Yet, increasingly, AI has become even more proliferated due to increasing technological advances that improve the accessibility and availability of AI to others. Coinciding with the decrease in barriers, that may have previously prevented the use and development of AI, governments around the world have begun to investigate how AI can be used in their day-to-day business processes. As AI is still relatively new, and developing at an increasing pace, governments are beginning to grapple with questions of how to best procure, use, and regulate AI. While these questions are becoming increasingly important, there is currently a lack of empirical evidence that can be used to generate insight and understanding into these questions, thus providing a clear opportunity and need for research that could provide such evidence.

In the public sector it is hoped that the use of AI will increase its effectiveness and efficiency, enable new forms of public service delivery and evidence-based policy making, or lead to the 'transformation' of the public sector (Berryhill et al., 2019). However, there are a number of risks that may also accompany the adoption of $\mathrm{AI}$ in the public sector on the quest to achieve such benefits, such as bias (Caliskan et al., 2017), privacy (Agarwal, 2018), or ethics (Andrews, 2019). In such situations, it becomes necessary for the public sector to develop strategies and regulations that would allow for the simultaneous harnessing of AI's benefits, while constraining the potential risks. One way to achieve this is through the use of well developed, targeted, and responsible public procurement methods, strategies, and guidelines that focus on how to conduct public procurement of AI. Indeed, well strategized and conducted procurement is likely key to the adoption of $\mathrm{AI}$ in government. As quoted in the House of Lords Select Committee on Artificial Intelligence:

'Most of GovTech is about procurement... getting procurement rules right is one of the most important parts of driving improvements in technology... [and] that [it] is a huge part of driving digital as a whole, including the take-up of AI' (House of Lords, 2018).

However, while public procurement is becoming increasingly important and relevant for public administration and management - it is a core capability for any public administrator (Snider \& Rendon, 2012) - recent research reviews appear to suggest that this is a research area that is currently underdeveloped. One such review, conducted by Trammell et al., 2020, highlighted that in public administration and management literature procurement topics make up less than $1 \%$ of the total volume of articles, and that public administration research could 'benefit from a better understanding of procurement processes and policies and their implications for research and practice' (p.665). Certainly, the topic of public procurement is becoming increasingly written about, especially in the context of increasing government digitalization and digital service development (Clarke, 2020). For example, there is research devoted to understanding the adoption of e-Procurement systems (Chen et al., 2021) and the use of public procurement in digital government initiatives (Concha et al., 2012), both clearly relevant for public administration and government digitalization; but, not necessarily widely applicable to the public procurement of AI. This is due to the fact that the procurement of AI is different when compared to traditional forms of public technological procurement.

While it may be possible to argue that previously conducted research on traditional public technological procurement is applicable to AI, indeed much of it is, in this paper it is argued that

${ }^{* * *}$ This is an early draft of the paper, please do not cite without the authors permission*** 
there are still fundamental differences in the form of procurement challenges between traditional procurement technological procurement and the public procurement of AI. As is argued later in this paper, these differences appear to primarily originate due to: challenges related to data ownership, automated decision making, ethics, bias, and discrimination, and hidden policy decisions taken in AI development processes.

Due to the presence of this difference between traditional public technological procurement and public procurement of AI, there appears to be at least two current needs. First, an empirical exploration on the nature of the public procurement of AI and its unique set of procurement challenges. Second, due to this difference, there is a need for a clear overview of how public administrations could approach the public procurement of AI, overcome encountered barriers and challenges, and develop the capacity to manage and undertake public procurement of $\mathrm{AI}$ systems. One of the most likely ways to do this is through the development and maintenance of guidelines for the public procurement of AI.

Thus, this paper aims to meet and provide initial input and exploration of both of these needs by asking and answering the questions of:

- What are the key challenges associated with the public procurement of AI?

- What are the commonly occurring strategies, recommendations, and guidelines to overcome such challenges?

In answering these research questions, this paper will make some key contributions to the current public administration and management literature. It argues and supports the differentiation between traditional public technological procurement and procurement of AI. It provides an overview of the unique challenges and barriers associated with the procurement of $\mathrm{AI}$ in the public sector. It divides these challenges and barriers into distinct categories, as well as the stage of the procurement process they make occur. And, finally, it offers some initial guidelines and policy-relevant insight into how to both develop the capacity within the public sector to procure AI better and offers potential solutions to common problems and challenges that could be included in future AI procurement guidelines.

Methodologically, this research paper utilizes a qualitative, exploratory, and comparative study of the public procurement of AI in four European countries. Estonia, Netherlands, Serbia, and the United Kingdom. Each country selected for this analysis has both acknowledged that there appears to be a difference between traditional public technological procurement and public procurement of AI and has begun to implement guidelines, strategies, or policies meant to aid public sector organizations in the AI procurement process.

The paper proceeds by starting with an initial literature overview of traditional procurement of innovation and technological procurement, discusses public procurement of AI, and offers some initial insights into the challenges that may be faced during the public procurement of AI. After the initial literature overview the methodology, empirical evidence sources used, and data analysis methods are presented. This is followed by a short overview of each of the selected case countries, the results of the analysis, a discussion of the findings and reflection on the current academic literature, and finally the answers to the research questions are elucidated, accompanying potential directions for future research and relevant policy and managerial insights. 


\section{Relevant Background Literature}

\section{Public Procurement of Innovation}

There are two strands of research often associated with procurement and the public sector. The first strand views procurement as a tool for NPM-type initiatives to transform the public sector into an organization more closely resembling the private sector (Drechsler, 2005; Trammell et al., 2020). Procurement, with respect to outsourcing, was seen as a way to improve governmental efficiency, drive down costs, and delegate service developments to the private sector. This, in turn, would allow the government to downsize and further save costs. However, it has now been shown that this approach weakens governmental ability to effectively deliver services and drives a transition towards becoming a 'hollow state' (Milward \& Provan, 2003). The second strand is that of public procurement of innovation (PPI), which rather explores how governments can use public procurement to drive innovation and create higher levels of public value. PPI is 'not limited only to buying non-existing products... but it is also about creating new capabilities (organizational and technological) as well as about innovation diffusion and gradual upgrading that the government purchasing decisions can stimulate' (Lember et al., 2015, p.404-405).

In both cases, the government acts as the purchaser and a supplier needs to provide a specific service or product by a specific time to reach specific goals or outcomes. The difference is about who is the primary driver of innovation, the private sector (or contractor) or the public sector (or funder) (Lember et al., 2015). In the case of this paper, procurement is rather viewed from the perspective of innovation.

This is becoming an increasingly relevant viewpoint in today's literature as governments continue to digitalize and move towards more integrated digital governments and electronic service delivery, and rely on procurement for said services (Trammell et al., 2020). In the context of AI, this approach becomes increasingly important as it should allow for government organizations to use their purchasing power to drive the creation of AI systems in line with their own regulatory and policy goals through procurement regulations.

\section{Process of Procurement}

When it comes to the actual process of procurement, it can be said that there are three primary phases: feasibility assessment, implementation and organization of procurement, and monitoring and evaluation of performance (Brown \& Potoski, 2003). In the first step, the public sector organization would notice that there was a need for a new service or innovation and an analysis of whether or not the capacity exists within the organization to develop this itself. In the case of a negative answer (for example if there are no AI experts within the organization), then the initial documentation would be drawn up, including the technical requirements, funding, and evaluation criteria. Finally, once a contractor has been chosen (this is often based on some combination of price, expertise, and excellence of the proposal) the procurement is begun and the progress is evaluated and monitored.

While the aforementioned approach is still the most common procurement strategy, newer forms of procurement have emerged, such as challenge-based procurement or pre-commercial procurement (Edquist \& Zabala-Iturriagagoitia, 2015). These innovative procurement methods have also encouraged the participation of smaller companies, SMEs, and start-ups, whereas previous and traditional procurement approaches favoured larger and more established companies. In the context of AI, this is an important distinction, as much AI capacity exists within start-ups and SMEs which governments are turning towards to reduce their reliance on large technological companies in an attempt to boost technological sovereignty.

\footnotetext{
${ }^{* * *}$ This is an early draft of the paper, please do not cite without the authors permission***
} 
By encouraging the use of new and innovative procurement methods, both companies and governmental organizations are exposed to opportunities they may not have had under traditional procurement approaches. Due to the fact that there are many suspected benefits associated with the use of innovative procurement methods, especially within the context of disruptive technologies, many governments make recommendations to use innovative procurement approaches; but, there is little interest in exploring or drafting guidelines on how these procurements should be organized and conducted, only that they should be. Thus, guidelines should be drafted to help decipher when one method is preferred over the other. However, while innovative procurement methods may well have a specific time and purpose, it is also important to ensure that they are not used to subvert regulatory and ethical requirements and obligations that governments may otherwise bind companies to during larger and more traditional procurement methods.

\section{Traditional Public Technological Procurement Success Factors}

In either case, whether traditional or innovative, there are a number of factors that influence the likelihood that a given procurement will succeed. One of the most relevant is that of contractmanagement capacity (Brown \& Potoski, 2003); the likelihood that a procurement is successful is highly dependent on how well the organization is able to manage the process. Second, the identification and formulation of necessary and relevant technical requirements before a procurement takes place (Edler et al., 2006; Georghiou et al., 2014). Third, it must be understood what the current market is actually able to produce, the creation of unrealistic requirements, or an over/underestimation of the current market will lead to potential failure (Edler et al., 2006; Knuttsson \& Thomassen, 2014; Mulligan \& Bamberger, 2019). Fourth, when it comes to understanding key ways to ensure that a procurement will be successful, Edquist et al., 2000 highlights three: timing, technical competence inside the procuring organization, and broader organizational competencies. Finally, for traditional public technological procurement, the organization must have a high degree of technical knowledge, or, if they do not have this capacity inside their own organization, must be able to coordinate the attainment of this knowledge (Edler et al., 2006; Edquist et al., 2000).

In the context of AI, this implies that governments must:

- have the ability to successfully manage AI procurement contracts,

- have the relevant technological knowledge and in-house capacities,

- be aware of the current market abilities and relevant state-of-the-art, and

- have an in-depth understanding of their own IT infrastructure, data, and capabilities.

However, as AI expertise in the public sector is scarce (Wirtz et al., 2019), administrations often have to collaborate to get AI capabilities (van Noordt \& Misuraca, 2020), and data governance regimes may be lacking (Janssen et al., 2020, 2017), public procurement of AI may well prove to be challenging for administrations, especially without additional guidance.

\section{Artificial Intelligence in the Public Sector}

When it comes to the public procurement of $\mathrm{AI}$ in the public sector, there are a number of different potential use cases, such as: chatbots or virtual assistants (Aoki, 2020; van Noordt \& Misuraca, 2019), natural language processing (Agarwal, 2018), computer vision (Tammiste, 2020), food safety (McBride et al., 2018), health care (Sadilek et al., 2018), predictive policing (Benbouzid, 2019), or automated decision making (Wihlborg et al., 2016). This is not a complete and comprehensive list, but, it does demonstrate that there a number of different ways in which AI can be used in the public sector. Each use case serves their own purpose, such as: improving 
internal efficiency, improving government citizen interaction, improving overall effectiveness, or allowing public servants to make better decisions and operate in an augmented manner.

However, each use case utilizes different models or algorithms and requires different data and infrastructure. In practice, this means that organizations will also require different data, in different formats, held in different ways, which are then used by different models and algorithms, which in turn require the availability of different infrastructural components and capabilities. Due to this mashup of systems, algorithms, and infrastructure, government organizations that rely on procuring their AI project development may well end up in a situation where their AI infrastructure represents a hodgepodge, with different solutions pieced together, rather than something more coherent and interoperable. There are a number of additional challenges that can materialize during the public procurement of AI, these are explored in more detail in the next section, but it is important to point out here that procuring AI systems can be complex, risky, and time consuming. In order to avoid increasing levels of complexity, some organizations may gravitate towards a single large provider, yet, this increases the likelihood of vendor lock-in and should probably be avoided.

\section{Challenges Associated with the Public Procurement of AI}

In traditional procurement of technology and public procurement of AI, the strategies, processes, and success factors are likely similar, as, ultimately, AI is a technology. However, there are a number of challenges unique to AI that do not necessarily manifest themselves in other technological procurements. Certainly, they are more common and more plentiful in the public procurement of AI. Thus, this section of the literature review aims to highlight primarily the challenges found in the public procurement of $\mathrm{AI}$, and in doing so help to make an initial differentiation between traditional public technological procurement and public procurement of AI.

One of the first challenges that appears during the public procurement of AI is that of data and the legal challenges that may arise as a result of using data in a machine learning service (Janssen et al., 2020). All machine learning algorithms require data to function, the question is, where does this data come from? In case the government is providing the data, they must ensure it is clear where the data can be held. Is it on their own servers, in a cloud, with the provider? The answer to this will depend based on the relevant regulations and legal requirements the procuring organization is subject to. It is also important to understand how a citizen's data could be removed from the relevant dataset should they request their data be forgotten. If data used in the algorithm is, for example, textual in nature, e.g. emails or chats sent to the government, how is it ensured that any personal information is removed from this data (Harrison \& Luna-Reyes, 2020).

A second challenge, also related to data, is that of data ownership and data sovereignty. If data is collected by a government, but then used by a private sector company to train an algorithm, can the company sell this trained algorithm to other countries, or can the procuring organization retain complete ownership over the data? This issue works in the reverse as well, in the case that data is coming from the private sector organization (Campion et al., 2020).

The potential for bias and discrimination in $\mathrm{AI}$ is a third clear challenge. It is apparent that many machine learning algorithms and tools exhibit human bias and discrimination (Caliskan et al., 2017) and these biases can have real impact if left to their own devices in the public sector. These issues have already materialized when algorithms are used in the public sector for services such as criminal sentencing (Washington, 2018) or predictive policing (Benbouzid, 2019). Furthermore, there needs to be an understanding on who bears responsibility for any potential bias or discriminatory algorithmic decisions. Is it the AI itself? Is it the government? The private

${ }^{* * *}$ This is an early draft of the paper, please do not cite without the authors permission*** 
sector? Such issues must be covered in either legal regulations, or via the procurement process itself. Some initial initiatives to address these issues have already begun to emerge. For example, both the OECD and the EU have drafted and released guidelines to address ethical creation and use of AI, so too has the council of Europe drafted initial guidelines for procuring AI systems that respect human rights.

A fourth issue associated with public procurement of $\mathrm{AI}$ is that of trade secrecy and intellectual property rights, which can effect algorithmic transparency (Brauneis \& Goodman, 2018; Mulligan $\&$ Bamberger, 2019). For example, a purchased AI solution may be used by a number of different organizations and, in this case, the provider of the service likely desires to protect their product, algorithm, and the data it uses. This could limit the government from providing this information to any concerned or effected stakeholders. An example of this can be seen in the 2016 court case Loomis v. Wisconsin. Here, the defendant argued that the COMPAS system used in a previous hearing, was biased (this has been backed up by research e.g. Larson et al., 2016) and wanted to review the algorithm, however for trade secret purposes (they could not disclose the algorithm or the methodology) this request was denied.

\section{Summary}

While many governments do have experience with traditional public technological procurement, the public procurement of $\mathrm{AI}$ is different. This differentiation is primarily due to challenges that appear unique to $\mathrm{AI}$, such as those related to data ownership, discrimination, bias, and the potential for hidden policy decisions embedded within utilized AI systems. By utilizing public procurement effectively, it is possible to embed values and regulations that should, in theory, be able to overcome, pre-empt, minimize, or prevent such negative externalities. This is especially the case in the public procurement of AI due to the heavy reliance across most public sector organizations on procurement for their AI developments. However, there is currently a gap on how to best organize and conduct such procurements. As the literature shows, if public procurement of AI is to be successful, there needs to be development of AI capacity within the public sector, what it is, how it works, what are the risks, challenges, how can these challenges be overcome, and, most importantly, how can AI be successfully procured. The literature does offer a number of insights into potentially relevant success factors for such procurements, such as market knowledge, contract management capacity, technological capacity, and data governance. In the case where these capacities are missing, one potential way to develop such capacities appears to be through the use of guidelines, frameworks, and educational programs to help develop and retain codified knowledge within the organization for how to best procure AI.

\section{Methodology}

After the initial literature review and desk research had been conducted it was clear that there was a need for research on the public procurement of AI. As Europe has made a commitment to innovative procurement and also the fostering of AI capacity a priority ${ }^{1}$, European states were selected for an initial review of relevant public procurement of AI guidelines. While, many countries acknowledged the importance of - promising to develop and implement - guidelines for the public procurement of $\mathrm{AI}^{2}{ }^{2}$ a substantial majority have not yet done so. There has been little to no actualization, implementation, or use of AI procurement guidelines. In fact, only four European countries had made clearly identifiable steps towards the development and

\footnotetext{
${ }^{1}$ See, for example: https://ec.europa.eu/transparency/regdoc/rep/1/2018/EN/COM-2018-795-F1-EN-MAIN-PART-1.PDF. Last accessed 8 Feb, 2021

${ }^{2}$ See, for example, the Al strategies of Belgium (though not an official government strategy, it is highly influential within Belgium), Malta, and Spain.
}

***This is an early draft of the paper, please do not cite without the authors permission*** 
implementation of AI procurement guidelines: Estonia, Netherlands, Serbia, and the United Kingdom. In the case of the United Kingdom and Estonia, guidelines already exist and are in use. In the case of the Netherlands and Serbia, there is a clear commitment to the creation of AI procurement guidelines and initial steps are already progressing. Thus, these four countries were chosen for further research and study.

Methodologically, this paper utilized an exploratory case study (Yin, 2018) approach to explore the AI procurement guidelines in each of the four selected countries. While case studies of an exploratory nature may be criticized, for the current research it is the correct and relevant method as it is a current and ongoing phenomena of importance for contemporary society, is under studied, and there is a current lack of clear empirical evidence on the topic (Eisenhardt, 1989; Yin, 2018). There is a large amount of literature on the importance of ethical guidelines for AI procurement, however, research often does not extend beyond this and, to the best knowledge of the authors, there is not currently existing research that focuses explicitly on how to: procure AI systems in the public sector, avoid common risks of AI deployment, overcome the challenges faced by the public sector when procuring AI, and develop the necessary capacities within the public sector to better procure AI. In such situations, case study research is justifiable and relevant.

In regard to the empirical evidence used in this study, a number of evidence sources were used to ensure the triangulation of the findings and thereby improve the internal validity of the study. These evidence sources were: semi-structured interviews, official policy documents, media sources, and, in some instances, direct observation. The nine semi-structured interviews were conducted with the leaders and users of the relevant AI procurement initiatives; interviewees have been anonymized and given a code based on their interview number and the country's guidelines they were involved with $^{3}$.

All conducted interviews were done virtually, lasted up to 45 minutes, were transcribed, and then analysed using conventional content analysis (Birks \& Mills, 2015; Hsieh \& Shannon, 2005). The interview questions all aimed to address different aspects of the public procurement of AI process, such as: internal organizational capacity, the procurement process, existing guidelines or best practices, AI development strategies, and any encountered barriers to AI adoption. Interviews were conducted after the initial document and textual based desk research and served as a way to get insight into the behind-the-scenes processes associated with the development or ideation of AI procurement guidelines. The primary documents analysed were the official AI strategies for each country (this exists in three out of 4 countries, the United Kingdom does not have an official AI Strategy, but rather a policy paper) and the existing and relevant AI procurement guidelines available within each country. Other documents analysed included training seminars recorded and published to YouTube, magazine articles, newspaper articles, and governmental hearings or reports, which were used to help support and frame the interviews.

A summary of the evidence methods used is provided below in Table 1.

$\{\{$ Table 1 about here $\}\}$

In regard to the potential shortcomings of this research it must be highlighted that this research offers only a preliminary view of the challenges faced during the public procurement of AI, as many of the guidelines studied are still currently under development or in a testing phase. One respondent, NL.PS1, noted that in the Netherlands there were difficulties in assessing the

\footnotetext{
${ }^{3}$ For a description if each interviewee, please see section 3 of the annex.
}

***This is an early draft of the paper, please do not cite without the authors permission*** 
usability of the created guidelines due to a lack of potential cases that they could be validated against. A second potential weakness is similarly related: there is a small bias in the analysed cases as they represent the most developed countries. How other administrations, with less experience, may address similar and/or other public procurement of AI challenges remains unknown; though there is likely to be significant overlap, it is not possible to make a strong statement to this effect, slightly limiting the external applicability of the research.

\section{Initial Overview of the Cases}

\section{Estonia}

Starting in 2016, Estonia began to develop a comprehensive strategic and regulatory approach to the adoption and implementation of $\mathrm{AI}$ in the public sector. These efforts were led and coordinated by the Estonian Ministry of Economic Affairs and Communication (MKM) and were focused on the regulation of self-driving vehicles in Estonia. In 2018, a task force was announced that was composed of AI experts, lawyers, and policy makers who were given the responsibility of developing an Estonia AI strategy. This strategy was finished and approved in 2019 and focused on four primary areas: advancing the uptake of AI in the public sector, advancing the uptake of $\mathrm{AI}$ in the private sector, developing $\mathrm{AI} R \& \mathrm{D}$ and education, and developing a legal environment for the uptake of AI (Riigikantselei \& MKM, 2019).

To help address a perceived general lack of knowledge and experience about best practices for AI procurement in the Estonian public sector, the chief data officer has created a number of different guidelines and tools for improving and aiding public sector officials with their procurements (EE.PS1, 2020; EE.PS2, 2020). These include: A questionnaire to decide if AI is the correct technology for a specific project; instruction materials with instructions, recommendations, and best practices for AI projects in the public sector; a reusable structure and template for AI procurements; an overview document for public servants about key terms and concepts in $\mathrm{AI}$; data impact assessments; and a number of training presentations and videos about different $\mathrm{AI}$ projects (MKM, 2020; EE.PS1-3, 2020).

\section{Netherlands}

In the Netherlands there has not been a national AI procurement guideline document published as of the time of writing. However, in the city of Amsterdam, AI procurement guidelines have been developed to assist with the responsible and democratic use and development of AI technologies within the city (NL.PS1, 2020) and are being evaluated for use at all administrative levels; the Association of Dutch Municipalities has also made the guidelines available for all municipalities to use. These guidelines consist of nine different articles that describe the various terms and conditions that AI systems should adhere to when they are procured by the municipality. These include transparency requirements, data ownership and governance requirements, AI system quality, risk management and maintenance. The guidelines are still in the testing phase, as the city aims to understand how different stakeholders, such as other municipalities, civil servants, smaller and bigger companies view and evaluate these guidelines (Amsterdam City, 2020).

The procurement guidelines should be followed whenever a contractor provides the city with an algorithm for decision making, decision support, enforcement, fraud investigations or a system to be used on the staff on the municipality. A key aspect is the requirement for AI to be transparent in three different ways: procedural, technical and explainable (Amsterdam City, 2020). This requires the contractor to document and describe the non-technical, core functioning of algorithm, the technical quality and operation such as the source code, and explainability of case

\section{***This is an early draft of the paper, please do not cite without the authors permission***}


by case outcomes, respectively. At all times should decisions with or by AI be explainable, as per requirement of Dutch public law.

\section{Serbia}

The Serbian government has released their strategy regarding the Development of AI in their country for the period 2020-2025. In this document, public procurement has been regarded as an important element to stimulate AI within Serbia. Public procurement is seen in the strategy as a tool to create market opportunities for start-ups and as an opportunity for the public sector to modernize public services (RS.PS1, 2020). The lack of a framework for the use of public procurement for innovative technologies such as $\mathrm{AI}$ is regarded as one of the key issues limiting the development of AI adoption in the Serbian public sector (RS.PS1, 2020). Hence, the strategy mentions the need to adopt public procurement regulations, and particularly to regulate issues regarding data ownership and to regulate algorithmic bias (Government of Serbia, 2019). In this respect, it is mentioned that public procurement contracts should include the obligation to assign data to the state and to define the structure, form, and format of the submitted data.

Currently no AI public procurement guidelines have been made available, but initial steps have been taken to establish a governmental AI Institute, which, once established, should assist the government in developing their own AI capacity, creating guidelines, AI procurements, AI projects and other AI related topics (RS.PS2 \& RS.PS3). As it has been regarded to be challenging to find AI experts and hire them in the public sector, most of the AI capacity is planned to be centralized within this governmental AI institute.

$U K$

The government of the United Kingdom partnered with the World Economic Forum to draft guidelines for AI procurement in the public sector. These guidelines specifically address challenges that public sector organizations may face during the public procurement of AI based solutions. Public procurement is regarded as the primary mechanism to facilitate the adoption of AI in the government (UK.PS1, 2021), which may be done to improve public sector delivery, reduce costs, improve effectiveness, or reduce administrative burden (World Economic Forum, 2020). In these guidelines, AI is understood as the use of digital technology to create systems that conduct intelligent tasks, but the document itself primarily refers to machine learning (Office of AI et al., 2020). Though the guidelines focus primarily on machine learning, they also acknowledge that there are fundamental differences between different AI-based systems and offers specific guidance for different AI use cases at different stages of readiness.

The guidelines provide a number of considerations during various stages of the AI procurement process. These guidelines make it clear that there is a pre-procurement process, which starts by assessing whether or not $\mathrm{AI}$ is truly needed and whether or not the relevant data or skillsets exist to develop and evaluate an AI system (World Economic Forum, 2020). Specific guidance is offered to assess whether or not an AI system is or is not needed. Further, the guidelines highlight the need to ensure transparency and explainability of AI system in the procurement, as this ensures future understandability of the system, and reduces the potential of vendor lock-in. The guidelines also highlight the importance of testing and evaluating AI systems, specifically by using data and impact assessments throughout the entire development process, from ideation through to implementation.

\section{Results and Discussion}

While there are similarities between traditional public technological procurement and public procurement of AI, all four countries' interviewees seemed to hold a similar belief: there is a

\footnotetext{
${ }^{* * *}$ This is an early draft of the paper, please do not cite without the authors permission***
} 
difference between traditional public procurement of technology and public procurement of AI and that this warranted the need for new guidelines. For example, UK-PS1 noted that they saw two reasons that the public procurement of AI should be treated differently than other forms of procurement:

'Yes, AI technology is similar to other technologies and technological procurement has been within government for quite some time... however, when you procure AI technologies you also, sometimes, make policy decisions. You basically are outsourcing, somewhat, policy decisions' and furthermore that, 'we thought about the public procurement of AI as a policy tool to drive innovation and regulation' (UK-PS1, 2021).

The importance of using procurement as a policy tool to drive innovation and regulation has also been mentioned in Serbia and the Netherlands.

While each of the countries selected had guidelines and approaches for AI procurement, the motivational reason behind them slightly differed. For example, in the Netherlands and the UK it was clear that AI procurement emphasis was given to viewing procurement as a policy tool, whereas in Serbia and Estonia AI procurement was emphasized as the means to stimulate and develop the AI ecosystem and private sector. Interestingly, in Estonia, Netherlands, and the United Kingdom interviewees suggested that the private sector, especially SMEs, were responsive and appreciative of the development of AI procurement guidelines as it helped to improve procurement clarity, relevance, and alignment with the market.

When it comes to the actual contents of the different public procurement of AI guidelines, during the research it was possible to identify and triangulate 14 key challenges faced during AI procurement as well as potential solutions and best practices to overcome such challenges. These challenges could further be subdivided into four categories: procurement processes challenges, data challenges, AI-model challenges, and organizational capacity challenges. An overview of these challenges, their explanation, potential solutions, their location within the procurement process, and the source for each is provided below in Table 2 .

$\{\{$ Table 2 about here $\}\}$

\section{Procurement process challenges}

The first group of challenges identified were those specific to the procurement process itself. As a starting point, it must be decided whether or not $\mathrm{AI}$ is actually needed for a specific problem as AI should not be applied just for the sake of using AI. To help public sector organizations overcome this problem checklists and guidelines have been prepared that allow for an organisation to assess whether or not an AI-based system should be procured; these checklists exist both in Estonia and the United Kingdom.

A second challenge, as was mentioned previously in the paper, is having an understanding of the market; this is critical for the success of a procurement. Addressing this issue, EE-PS1 noted during an interview that in Estonia there were problems with procurement from the public sector and the market let them know. However, while there were challenges with the public procurement of AI, 'it's not AI specific, a lot of procurement of anything IT is quite crappy anyways, right. That's a problem in itself' (EE-PS1, 2020). Yet, even so, the interviewee continued on to note that after the chief data officer had 'come up with an instruction manual or a guidance paper about how to procure these things' and that since then, they 'hear from the market, [that] it has gotten better' (EE-PS1, 2020). Similar sentiment was offered by UK-PS1, who noted that there 'was a very positive narrative from the private sector' and that the new guidelines 'made it easier for the private sector to reply or participate in procurement' (UK-PS1, 2021) as well as NL-

$* * *$ This is an early draft of the paper, please do not cite without the authors permission*** 
PS1, who stated that companies found the produced guidelines 'quite logical and reasonable' (NLPS1, 2021).

In regard to the trade secrecy challenges, it is important to ensure that government organizations are not stuck in a situation where they are not able to share relevant information about how a specific algorithm or AI-system functions if requested. In the guidelines from the United Kingdom and the Netherlands specific guidance is given on how to ensure sufficient documentation and transparency of AI systems. An additional way to do this, as highlighted by Brauneis \& Goodman, 2018 is to place importance on 'contract language requiring provision and permitting of disclosure of records' therefore 'placing the burden on the contractor to identify and mark specific passages in a document as trade secrets' and subsequently '[linking] disclosure provisions to demands that records be produced to the government' (p.164-165).

Finally there is the challenge of procurement structure. In Estonia, the chief data officer has created a standardized template with accompanying questionnaires that can be used by organizations to aid them in the procurement process. Interviewees EE-PS2 and EE-PS3 both noted that this guidance and structure was helpful for their organizations in the procurement process. Such templates and structured documents were not readily apparent in the other studied countries.

\section{Data challenges}

The second group of challenges are those related to data, namely its availability, governance, ownership, and infrastructure. In all four of the countries studied, the role of data in AI procurement was given prominence. For example, in Serbia, RS-PS2 noted that there needed to be clear guidelines on how to give data away in an organized way and how such data should be stored, arguing that data infrastructure must be developed before engaging in AI procurement. Additionally, in the Serbian AI strategy, it is noted that 'public procurements and contracts must contain... the provider's obligation to assign [data] to state authorities' (Government of Serbia, 2020). Thus, when it comes to data governance and data ownership, specific measures should be in place for ensuring that there are proper regulations and governance mechanisms in place for data consumed or generated by AI-systems. Similar arguments existed in all countries studied.

In regard to data availability, there are two separate aspects at play. First, whether or not the data needed for a specific AI-system actually exists. To this end, the United Kingdom guidelines strongly recommended to assess the data quality and availability prior to any tender as to understand possible issues of the data available for the procured AI system. In Estonia organizations have the opportunity to engage in deep dive sessions with the chief data officer and private sector experts to explore the organization's available data and potential AI use cases. The second aspect related to data availability is ensuring that sample data is available and provided during the procurement process. This aspect was highlighted as being important by interviewees from the United Kingdom and Estonia.

\section{AI-model challenges}

The third grouping of challenges are those related to the AI-model or system itself and concern the quality, transparency, and bias of the system.

In regard to transparency and bias of AI-systems, all four countries made explicit commitment to the procurement of transparent, ethical, and unbiased AI. As has been mentioned previously in this paper, there are a number of international initiatives that layout clear guidelines and mechanisms to ensure this, such as the OECD's principles on Artificial Intelligence of the European Union's Ethics Guidelines for Trustworthy AI. Within the procurement guidelines

\footnotetext{
${ }^{* * *}$ This is an early draft of the paper, please do not cite without the authors permission***
} 
studied for this paper, only the United Kingdom and the Netherlands had their own guidelines in place for how this was to be done. For Estonia and Serbia only mentions to the aforementioned international guidelines were included.

When it comes to ensuring ethical and bias free AI procurement, a number of solutions have been suggested. For example, there are checklists, tools, and reviews that should help to check for bias and ethical issues in AI systems. ${ }^{4}$ It is also possible to require clear documentation about how the algorithm itself works, how decisions are made, what data are used for making such decisions, requiring explainability and interpretability in the technical description of the procurement documents, requiring contractors to provide and confirm their compatibility with specific guidelines, and utilizing iterative assessments of utilized AI systems (Berryhill et al., 2019; Brauneis \& Goodman, 2018; Mulligan \& Bamberger, 2019).

\section{Organizational capacity challenges}

The final category is that of organizational challenges, these are primarily associated with capacities at the managerial, technical, and individual levels.

In order for AI procurements to be successful, it is important that an organization develops and maintains the ability to procure AI well. In the case of Serbia, all interviewees noted that there was currently little capacity for procuring $\mathrm{AI}$ as there is a general lack of expertise. To counteract this, they have proposed to establish a government-academic collaborative institute to aid the government in future AI procurement. Similarly, in Estonia, the private sector and the chief data officer have worked with different organizations directly to improve understanding of AI, organized educational programs, and provided clear documentation to common questions and problems. Across all countries studied, it was noted that there was a clear need to improve the AI and technological capacity of organizations. This can be done by encouraging participation and availability of AI programs, as well by making IT experts available across organizations. For example, in the United Kingdom it has been noted that if there is missing capacity: 'you should seek [assistance] from elsewhere in your organization or relevant professional network.... And make the consultation and collaboration with appropriate stakeholders a priority' (World Economic Forum, 2020).

\section{Conclusions}

The use of AI in public sector organizations is becoming increasingly important and common. While many governments already have substantial experience with digitalization, they often have adopted different strategies when it comes to how they drive their technological development (e.g. outsourced vs in house capacities). ${ }^{5}$ However, with AI, it is likely that most countries, at least at the start, will procure development of AI solutions due the concentration of AI expertise in the private sector, and especially in smaller start-ups and SMEs. Additionally, the public procurement of AI comes with a number of challenges that sets it apart from other traditional modes of procurement. In this paper, it is acknowledged that the current public administration and management literature currently falls short when it comes to interaction with public procurement topics, and, additionally, has little to no empirical work dealing specifically with the public procurement of AI. One of the primary contributions of this research paper finds its place

\footnotetext{
${ }^{4}$ See, for example: Ethics and Algorithms Toolkit, Aequitas, Canada's Algorithmic Impact Assessment, and the United Kingdom's review into algorithmic bias.

${ }^{5}$ some have in-house ICT capacities (UK and Germany) others have outsourced their ICT capacities (Estonia),

***This is an early draft of the paper, please do not cite without the authors permission***
} 
here: it outlines the public procurement of $\mathrm{AI}$ and posits that it must be dealt with differently than traditional forms of technological procurement.

The other major contributions of this paper are realized in the answering of the research questions. In regard to the first research question, 'what are the key challenges associated with the public procurement of AI?' the paper draws on the experiences in drafting public procurement of AI guidelines from Estonia, Netherlands, Serbia, and the United Kingdom to identify 14 key challenges in four categories. These categories were procurement process challenges, data challenges, AI-model challenges, and organizational capacity challenges. In regard to the second research question, 'what are the commonly occurring strategies, recommendations, and guidelines to overcome such challenges?' a total of 22 potential strategies have been identified. This initial work should serve as a strong foundation for any public sector organization interested in developing their own AI procurement guidelines. For scholars, this work represents one of the first attempts to identify and categorize the challenges and best practices for procurement of AI and thus is likely to be of interest for those studying procurement and the public sector.

While this initial research has provided a strong foundation on AI procurement, future research is still needed on the topic. In the course of this research, it became clear that there is a wide breadth given between governments about what is considered $A I$ and which technologies are not. Further clarification about this should be sought in future research on the topic of public procurement of AI. Similarly, in this study it became clear that guidelines were just that, guidelines, there was often no obligation to use or implement them. In this way the guidelines may well help procurements to be successful, e.g. by providing guidance on how to write procurements better, but does not necessarily guarantee the relevant regulations and safeguards for ethical and unbiased AI are taken into account. Furthermore, if these guidelines are applied differently amongst cities, agencies, or organizations, it could lead to an uneven playing field with some areas being at an advantage and others at a disadvantage. In this respect, there is a strong need to convergence of standards and regulation both within national as well as international contexts.

As far as uneven playing fields go, there is a similar dilemma at play between larger and more established companies and smaller startups and SMEs. The former has the institutional notoriety and procurement knowhow, but may lack the ability to provide innovations at speed for lower costs, whereas the latter may be nimble, cheap, agile, and innovative, yet lack the prowess to participate in procurements. To this end, the procurement of AI must attempt to find a balanced approach, this can be precipitated through the use of innovative procurement methods, or through the use specifically targeted guidelines. Interestingly, in the interviews conducted, it became clear that most private sector companies (both larger organizations and startups) preferred when governmental organizations had clear guidelines in place as this made the initial procurement requirements clearer.

While guidelines are apparently important for the public procurement of AI, there are a number of other important and relevant issues that must be explored within the context of public administration and management studies. These aspects include how can AI be integrated into traditionally existing legacy infrastructural systems, how to address the legal and regulatory challenges associated with AI, how do environmental and cultural aspects influence the adoption of AI, how does context influence the ethical implications of AI. Outside of these concerns, there is also a need to further explore how to develop the relevant organizational capacities and culture needed to ensure successful public procurement of AI. In other words, there is a clear need for

\footnotetext{
${ }^{* * *}$ This is an early draft of the paper, please do not cite without the authors permission***
} 
extensive and comprehensive research within the domain of public administration and management on the subject of public procurement of AI.

It is certain that $\mathrm{AI}$ is here to stay in the public sector and that procurement will play an increasingly important role in the adoption of AI amongst public sector organizations. In effect, this also raises both the prominence and the need for scholars and experts to conduct research on this emerging area of inquiry.

It is critical that scholars and governments alike to collaborate and cooperate to make a conscious effort toward generating research and knowledge about the required administrative and organizational capacities needed for the successful public procurement of AI, that procurements can be conducted successfully, that guidelines exist for this process, and that the public procurement of $\mathrm{AI}$ is used to generate a positive impact and public value for society. 


\section{References}

Agarwal, P. K. (2018). Public Administration Challenges in the World of AI and Bots. Public Administration Review, 78(6), 917-921.

Amsterdam City. (2020). Explanatory Memorandum to the Standard Clauses for Municipalities for Fair Use of Algorithmic Systems. Available from: https://assets.amsterdam.nl/publish/pages/934668/explanatory_memorandum_to_the_st andard_clauses_web.pdf. Last accessed: 14 February, 2021.

Andrews, L. (2019). Public administration, public leadership and the construction of public value in the age of the algorithm and 'big data.' Public Administration, 97(2), 296-310.

Aoki, N. (2020). An experimental study of public trust in AI chatbots in the public sector. Government Information Quarterly, 37(4).

Benbouzid, B. (2019). To predict and to manage. Predictive policing in the United States. Big Data \& Society, 6(1), 1-13.

Berryhill, J., Kok Heang, K., Clogher, R., \& McBride, K. (2019). Hello, World: Artificial intelligence and its use in the public sector (Vol. 36). OECD Publishing.

Birks, M., \& Mills, J. (Jane E. (2015). Grounded theory : a practical guide (2nd ed.). SAGE.

Brauneis, R., \& Goodman, E. P. (2018). Algorithmic Transparency for the Smart City. Yale Journal of Law and Technology, 20(103), 103-176.

Brown, T. L., \& Potoski, M. (2003). Contract-management capacity in municipal and county governments. Public Administration Review, 63(2), 153-164.

Caliskan, A., Bryson, J. J., \& Narayanan, A. (2017). Semantics derived automatically from language corpora contain human-like biases. Science, 356(6334), 183-186.

Campion, A., Gasco-Hernandez, M., Jankin Mikhaylov, S., \& Esteve, M. (2020). Overcoming the Challenges of Collaboratively Adopting Artificial Intelligence in the Public Sector. Social Science Computer Review, 1-16.

Concha, G., Astudillo, H., Porrua, M., \& Pimenta, C. (2012). E-Government procurement observatory, maturity model and early measurements. Government Information Quarterly, 29(Supplement 1), S43-S50.

Chen, Y., Bretschneider, S., Stritch, J. M., Darnall, N., \& Hsueh, L. (2021). E-procurement system adoption in local governments: the role of procurement complexity and organizational structure. Public Management Review, (Ahead of print), 1-23.

Clarke, A. (2020). Digital government units: what are they, and what do they mean for digital era public management renewal?. International Public Management Journal, 23(3), 358-379.

Drechsler, W. (2005). The rise and demise of the new public management. Post-Autistic Economics Review, 33(14), 17-28.

Edler, J., Ruhland, S., Hafner, S., Rigby, J., Georghiou, L., Hommen, L., Rolfstam, M., Charles, E., Tsipouri, L., \& Papadakou, M. (2006). Innovation and Public Procurement. Review of Issues at Stake. In Study for the European Commission (No ENTR/03/24); (2006). Fraunhofer Institute for Systems and Innovation Research.

Edquist, C., \& Zabala-Iturriagagoitia, J. M. (2015). Pre-commercial procurement: a demand or supply policy instrument in relation to innovation?. R\&D Management, 45(2), 147-160.

\section{***This is an early draft of the paper, please do not cite without the authors permission***}


Edquist, C., Hommen, L., \& Tsipouri, L. (Eds.). (2000). Public Technology Procurement and Innovation (Vol. 16). Springer US.

Eisenhardt, K. M. (1989). Building Theories from Case Study Research. Academy of Management Review, 14(4), 532-550.

Georghiou, L., Edler, J., Uyarra, E., \& Yeow, J. (2014). Policy instruments for public procurement of innovation: Choice, design and assessment. Technological Forecasting and Social Change, 86, $1-12$.

Government of Serbia. (2019). Strategy for the Development of Artificial Intelligence in the Republic of Serbia for the period 2020-2025. Available from: https://www.srbija.gov.rs/extfile/sr/437310/strategy_artificial_intelligencecondensed261219_2.docx. Last accessed: 14 February, 2021.

Harrison, T. M., \& Luna-Reyes, L. F. (2020). Cultivating Trustworthy Artificial Intelligence in Digital Government. Social Science Computer Review, 1-18.

House of Lords. (2018). HOUSE OF LORDS Select Committee on Artificial Intelligence AI in the UK: ready, willing and able? Report of Session 2017-19. Available from: https://publications.parliament.uk/pa/ld201719/ldselect/ldai/100/100.pdf. $\quad$ Last accessed: 14 February, 2021.

Hsieh, H.-F., \& Shannon, S. E. (2005). Three Approaches to Qualitative Content Analysis. Qualitative Health Research, 15(9).

Janssen, M., Brous, P., Estevez, E., Barbosa, L. S., \& Janowski, T. (2020). Data governance: Organizing data for trustworthy Artificial Intelligence. Government Information Quarterly, $37(3)$.

Janssen, M., Konopnicki, D., Snowdon, J. L., \& Ojo, A. (2017). Driving public sector innovation using big and open linked data (BOLD). Information Systems Frontiers, 19(2), 189-195.

Knutsson, H., \& Thomasson, A. (2014). Innovation in the Public Procurement Process: A study of the creation of innovation-friendly public procurement. Public Management Review, 16(2), 242-255.

Larson, J., Mattu, S., Kirchner, L., \& Angwin, J. (2016, May). How We Analyzed the COMPAS Recidivism Algorithm - ProPublica. Propublica. Available from: https://www.propublica.org/article/how-we-analyzed-the-compas-recidivism-algorithm. Last accessed: 14 February, 2021.

Lember, V., Kattel, R., \& Kalvet, T. (2015). Quo vadis public procurement of innovation? Innovation, 28(3), 403-421.

McBride, K., Aavik, G., Toots, M., Kalvet, T., \& Krimmer, R. (2018). How does open government data driven co-creation occur? Six factors and a 'perfect storm'; insights from Chicago's food inspection forecasting model. Government Information Quarterly, (36)1, 88-97.

Milward, H. B., \& Provan, K. (2003). Managing the hollow state collaboration and contracting. Public Management Review, 5(1), 1-18.

Majandus ja Kommunikatsiooniministeerium (MKM). (2020). Juhendmaterjalid. [Mangement material]. Available from: https://www.kratid.ee/juhendmaterjalid. Last accessed: 14 February, 2021.

\section{${ }^{* * *}$ This is an early draft of the paper, please do not cite without the authors permission***}


Mulligan, D. K., \& Bamberger, K. A. (2019). Procurement as policy: Administrative process for machine learning. Berkeley Tech. LJ, 34, 773.

Office for AI, World Economic Forum, Government Digital Service, Government Commercial Function, \& Crown Commercial Service. (2020). Guidelines for AI procurement. Available from: https://www.gov.uk/government/publications/guidelines-for-aiprocurement/guidelines-for-ai-procurement. Last accessed: 14 February, 2021

Riigikantselei, \& MKM. (2019). Eesti tehisintellekti kasutuselevõtu eksperdirühma aruanne. [Report of Estonia's Artificial Intelligence Expert Working Group]. Available from: https://f98cc689-5814-47ec-86b3db505a7c3978.filesusr.com/ugd/0b32e3 9e397d14453b454db0b8d3615a7012ba.pdf. Last accessed: 14 February, 2021.

Sadilek, A., Caty, S., DiPrete, L., Mansour, R., Schenk, T., Bergtholdt, M., Jha, A., Ramaswami, P., \& Gabrilovich, E. (2018). Machine-learned epidemiology: real-time detection of foodborne illness at scale. Npj Digital Medicine, 1(1), 36.

Snider, K. F., \& Rendon, R. G. (2012). Public procurement: Public administration and public service perspectives. Journal of Public Affairs Education, 18(2), 327-348.

Tammiste, T. (2020, October). How Fyma turned cameras into sensors for AI-based traffic analytics in Dubai . Medium. Available from: https://medium.com/visory/how-visory-turnedcameras-into-sensors-for-ai-based-traffic-analytics-in-dubai-3def23f6eb55. Last accessed: 14 February, 2021.

Trammell, E., Abutabenjeh, S., \& Dimand, A.-M. (2020). A Review of Public Administration Research: Where Does Public Procurement Fit In? International Journal of Public Administration, 43(8), 655-667.

van Noordt, C., \& Misuraca, G. (2020). Exploratory Insights on Artificial Intelligence for Government in Europe. Social Science Computer Review

van Noordt, C., \& Misuraca, G. (2019). New Wine in Old Bottles: Chatbots in Government: Exploring the Transformative Impact of Chatbots in Public Service Delivery. Lecture Notes in Computer Science (Including Subseries Lecture Notes in Artificial Intelligence and Lecture Notes in Bioinformatics), 11686 LNCS, 49-59.

Washington, A. L. (2018). How to Argue with an Algorithm: Lessons from the COMPAS-ProPublica Debate. Colorado Technology Law Journal, 17(1), 131-160.

Wihlborg, E., Larsson, H., \& Hedstrom, K. (2016). “The Computer Says No!” -- A Case Study on Automated Decision-Making in Public Authorities. 49th Hawaii International Conference on System Sciences (HICSS 2016), 2903-2912.

Wirtz, B. W., Weyerer, J. C., \& Geyer, C. (2019). Artificial Intelligence and the Public SectorApplications and Challenges. International Journal of Public Administration, 42(7), 596-615.

World Economic Forum. (2020). AI Procurement in a Box: Project overview Unlocking Public Sector AI. Available from: http://www3.weforum.org/docs/WEF AI Procurement in a Box Project Overview 2020. pdf. Last accessed: 14 February, 2021.

Yin, R. K. (2018). Case Study Research and Applications: Design and Methods (6th ed.). SAGE Publications.

\section{$* * *$ This is an early draft of the paper, please do not cite without the authors permission***}


${ }^{* * *}$ This is an early draft of the paper, please do not cite without the authors permission*** 


\section{Annex}

1. Table 1

Table 1 Summary of Empirical Evidence Sources Used. Source (Authors).

\begin{tabular}{|c|c|c|c|c|}
\hline Country & Interviews & AI Strategies & Guidelines & Other Sources \\
\hline Estonia & $\begin{array}{l}\text { EE.PS1 } \\
\text { EE.PS2 } \\
\text { EE.PS3 }\end{array}$ & $\frac{\text { Estonian AI }}{\text { Strategy }}$ & 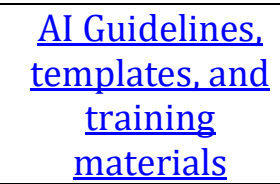 & 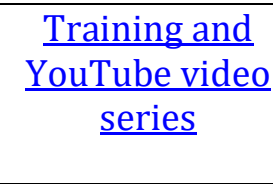 \\
\hline The Netherlands & NL.PS1 & $\frac{\text { Netherlands AI }}{\text { Strategy }}$ & $\frac{\text { Standard }}{\text { Clauses }}$ & $\begin{array}{l}\text { Dutch AI } \\
\text { Magazine }\end{array}$ \\
\hline Serbia & $\begin{array}{l}\text { RS.PS1 } \\
\text { RS.PS2 } \\
\text { RS.PS3 } \\
\text { RS.PS4 }\end{array}$ & $\begin{array}{l}\text { Serbia AI } \\
\text { Strategy }\end{array}$ & $\begin{array}{c}\text { Included inside } \\
\text { Serbia AI } \\
\text { strategy }\end{array}$ & \\
\hline $\begin{array}{l}\text { The United } \\
\text { Kingdom }\end{array}$ & UK.PS1 & $\underline{\text { AI Sector Deal }}$ & Guidelines & $\begin{array}{l}\frac{\text { Procurement in }}{\underline{\text { a Box }}} \\
\frac{\text { House of Lords }}{\text { Report }}\end{array}$ \\
\hline
\end{tabular}


2. Table 2

Table 2 Overview of challenges associated with procurement of Al and their potential solutions. Source: (Authors).

\begin{tabular}{|c|c|c|c|c|}
\hline Challenge & Explanation & $\begin{array}{l}\text { Procurement } \\
\text { process stage }\end{array}$ & Solutions & Source(s) \\
\hline \multicolumn{5}{|c|}{ Procurement Process Challenges } \\
\hline $\begin{array}{l}\text { Market } \\
\text { knowledge }\end{array}$ & $\begin{array}{l}\text { There is } \\
\text { knowledge } \\
\text { about the state- } \\
\text { of-the-art and } \\
\text { what currently is } \\
\text { or is not possible } \\
\text { in the market, as } \\
\text { well as correct } \\
\text { and relevant } \\
\text { pricing }\end{array}$ & $\begin{array}{l}\text { Feasibility } \\
\text { assessment }\end{array}$ & $\begin{array}{l}\text { 1. Engage in market } \\
\text { research to understand } \\
\text { the state-of-the-art and } \\
\text { whether or not a } \\
\text { specific project is } \\
\text { feasible. }\end{array}$ & $\begin{array}{l}\text { Estonia, } \\
\text { United } \\
\text { Kingdom }\end{array}$ \\
\hline Trade secrecy & $\begin{array}{l}\text { There is an } \\
\text { understanding } \\
\text { about who owns } \\
\text { the intellectual } \\
\text { property of the } \\
\text { procured } \\
\text { system. }\end{array}$ & $\begin{array}{l}\text { Implementation } \\
\text { and } \\
\text { organization of } \\
\text { procurement }\end{array}$ & $\begin{array}{l}\text { 1. Include specific } \\
\text { regulations within the } \\
\text { procurement on trade } \\
\text { secrecy and intellectual } \\
\text { property rights. } \\
\text { 2. Ensure that proper } \\
\text { documentation is } \\
\text { provided and } \\
\text { mandated in } \\
\text { procurement } \\
\text { documents. }\end{array}$ & $\begin{array}{l}\text { Netherlands, } \\
\text { United } \\
\text { Kingdom }\end{array}$ \\
\hline Service needs & $\begin{array}{l}\text { AI is the best } \\
\text { solution for the } \\
\text { specific problem }\end{array}$ & $\begin{array}{l}\text { Feasibility } \\
\text { assessment, } \\
\text { monitoring and } \\
\text { evaluation of } \\
\text { performance }\end{array}$ & $\begin{array}{l}\text { 1. Engage in a pre- } \\
\text { procurement process } \\
\text { to check whether or } \\
\text { not AI is the best } \\
\text { solution for a specific } \\
\text { problem }\end{array}$ & $\begin{array}{l}\text { Estonia, } \\
\text { Netherlands, } \\
\text { Serbia, } \\
\text { United } \\
\text { Kingdom, }\end{array}$ \\
\hline Structure & $\begin{array}{l}\text { There is a clear } \\
\text { structure to the } \\
\text { AI procurement } \\
\text { that enables the } \\
\text { suppliers to } \\
\text { clearly } \\
\text { understand what } \\
\text { is needed and } \\
\text { what the } \\
\text { requirements } \\
\text { are }\end{array}$ & $\begin{array}{l}\text { Implementation } \\
\text { and } \\
\text { organization of } \\
\text { procurement }\end{array}$ & $\begin{array}{l}\text { 1. Create standard } \\
\text { procurement templates } \\
\text { to ensure consistency } \\
\text { and validity of AI } \\
\text { procurements. }\end{array}$ & Estonia \\
\hline \multicolumn{5}{|c|}{ Data Challenges } \\
\hline $\begin{array}{l}\text { Data } \\
\text { availability }\end{array}$ & $\begin{array}{l}\text { Making the data } \\
\text { required for the } \\
\text { AI development } \\
\text { available, } \\
\text { accessible, or } \\
\text { obtainable }\end{array}$ & $\begin{array}{l}\text { Feasibility } \\
\text { assessment }\end{array}$ & $\begin{array}{l}\text { 1. Conducting a data } \\
\text { availability assessment } \\
\text { prior to the } \\
\text { procurement process } \\
2 \text {. Ensuring data access, } \\
\text { storage and consent }\end{array}$ & $\begin{array}{l}\text { Estonia, } \\
\text { United } \\
\text { Kingdom }\end{array}$ \\
\hline
\end{tabular}

${ }^{* * *}$ This is an early draft of the paper, please do not cite without the authors permission ${ }^{* * *}$ 


\begin{tabular}{|c|c|c|c|c|}
\hline & & & $\begin{array}{l}\text { before the } \\
\text { procurement }\end{array}$ & \\
\hline $\begin{array}{l}\text { Data } \\
\text { ownership }\end{array}$ & $\begin{array}{l}\text { Understanding } \\
\text { who owns which } \\
\text { data is used or } \\
\text { created by the AI } \\
\text { system }\end{array}$ & $\begin{array}{l}\text { Implementation } \\
\text { and } \\
\text { organization of } \\
\text { procurement }\end{array}$ & $\begin{array}{l}\text { 1. Ensure that the } \\
\text { procurement has } \\
\text { specific language that } \\
\text { data provided by the } \\
\text { public administration, } \\
\text { or collected in the } \\
\text { context of } \\
\text { procurement, remains } \\
\text { with the } \\
\text { administration. }\end{array}$ & $\begin{array}{l}\text { Estonia, } \\
\text { Netherlands, } \\
\text { Serbia } \\
\text { United } \\
\text { Kingdom }\end{array}$ \\
\hline $\begin{array}{l}\text { Data } \\
\text { governance }\end{array}$ & $\begin{array}{l}\text { Having the } \\
\text { necessary } \\
\text { governance and } \\
\text { legal } \\
\text { mechanisms are } \\
\text { in place for } \\
\text { sharing, } \\
\text { collecting, and } \\
\text { disseminating } \\
\text { data }\end{array}$ & $\begin{array}{l}\text { Feasibility } \\
\text { assessment }\end{array}$ & $\begin{array}{l}\text { 1. Ensure that } \\
\text { contractor has } \\
\text { followed regulation } \\
\text { and standards during } \\
\text { the collection of their } \\
\text { data as well as storage. }\end{array}$ & $\begin{array}{l}\text { Estonia, } \\
\text { Netherlands, } \\
\text { Serbia, } \\
\text { United } \\
\text { Kingdom }\end{array}$ \\
\hline $\begin{array}{l}\text { Data } \\
\text { infrastructure }\end{array}$ & $\begin{array}{l}\text { Understanding } \\
\text { the necessary } \\
\text { infrastructure } \\
\text { and its location } \\
\text { for a specific AI } \\
\text { project (e.g. Own } \\
\text { premises, in the } \\
\text { cloud, with } \\
\text { provider) }\end{array}$ & $\begin{array}{l}\text { Feasibility } \\
\text { assessment }\end{array}$ & $\begin{array}{l}\text { 1. Systematically } \\
\text { analyse the current } \\
\text { infrastructural } \\
\text { capabilities of your } \\
\text { organization and make } \\
\text { it clear within the } \\
\text { procurement. }\end{array}$ & $\begin{array}{l}\text { Estonia, } \\
\text { Serbia, } \\
\text { United } \\
\text { Kingdom }\end{array}$ \\
\hline \multicolumn{5}{|c|}{ AI-model Challenges } \\
\hline $\begin{array}{l}\text { AI system } \\
\text { quality }\end{array}$ & $\begin{array}{l}\text { The finished } \\
\text { system/model is } \\
\text { of high quality } \\
\text { and in line with } \\
\text { legal regulations } \\
\text { over a longer } \\
\text { period of time. }\end{array}$ & $\begin{array}{l}\text { Implementation } \\
\text { and } \\
\text { organization of } \\
\text { procurement, } \\
\text { Monitoring and } \\
\text { evaluation of } \\
\text { performance }\end{array}$ & $\begin{array}{l}\text { 1. Apply risk } \\
\text { management strategy } \\
\text { to identify and mitigate } \\
\text { risks } \\
2 \text {. Ensure maintenance } \\
\text { (over a period of time) } \\
\text { is contractually } \\
\text { obligatory }\end{array}$ & $\begin{array}{l}\text { Netherlands, } \\
\text { United } \\
\text { Kingdom }\end{array}$ \\
\hline $\begin{array}{l}\text { AI } \\
\text { transparency }\end{array}$ & $\begin{array}{l}\text { The AI system is } \\
\text { transparent and } \\
\text { explainable, } \\
\text { potentially for an } \\
\text { audit if deemed } \\
\text { necessary. }\end{array}$ & $\begin{array}{l}\text { Implementation } \\
\text { and } \\
\text { organization of } \\
\text { procurement, } \\
\text { monitoring and } \\
\text { evaluation of } \\
\text { performance }\end{array}$ & $\begin{array}{l}\text { 1. Including technical, } \\
\text { procedural and } \\
\text { explainability as } \\
\text { mandatory } \\
\text { requirements } \\
\text { 2. Explainability and } \\
\text { interpretability of } \\
\text { algorithms as a design } \\
\text { criteria } \\
\text { 3. Require clear } \\
\text { documentation about } \\
\text { the functionality of the }\end{array}$ & $\begin{array}{l}\text { Estonia, } \\
\text { Netherlands, } \\
\text { United } \\
\text { Kingdom, }\end{array}$ \\
\hline
\end{tabular}

${ }^{* * *}$ This is an early draft of the paper, please do not cite without the authors permission ${ }^{* * *}$ 


\begin{tabular}{|c|c|c|c|c|}
\hline & & & $\begin{array}{l}\text { AI-system, the data } \\
\text { used, and how it works } \\
\text { (at a minimum) }\end{array}$ & \\
\hline AI bias & $\begin{array}{l}\text { Potential bias of } \\
\text { an AI system is } \\
\text { mitigated as } \\
\text { much as possible }\end{array}$ & $\begin{array}{l}\text { Implementation } \\
\text { and } \\
\text { organization of } \\
\text { procurement, } \\
\text { monitoring and } \\
\text { evaluation of } \\
\text { performance }\end{array}$ & $\begin{array}{l}\text { 1. Conducting a data } \\
\text { assessment to identify } \\
\text { and address data bias } \\
\text { 2. Measures have to be } \\
\text { taken by contractor to } \\
\text { ensure bias is limited. } \\
\text { Iterative AI impact } \\
\text { assessments at crucial } \\
\text { decisions points should } \\
\text { be conducted. } \\
\text { 3. Obligatory } \\
\text { documentation on } \\
\text { compliance to non- } \\
\text { discrimination, equal } \\
\text { treatment and } \\
\text { proportionality }\end{array}$ & $\begin{array}{l}\text { Estonia, } \\
\text { Netherlands, } \\
\text { United } \\
\text { Kingdom, }\end{array}$ \\
\hline \multicolumn{5}{|c|}{ Organizational capacity challenges } \\
\hline $\begin{array}{l}\text { Technical } \\
\text { capacity }\end{array}$ & $\begin{array}{l}\text { The organization } \\
\text { has the } \\
\text { necessary } \\
\text { technical } \\
\text { capacities to } \\
\text { implement and } \\
\text { procure an AI- } \\
\text { based system }\end{array}$ & $\begin{array}{l}\text { Feasibility } \\
\text { assessment, } \\
\text { implementation } \\
\text { and } \\
\text { organization of } \\
\text { procurement }\end{array}$ & $\begin{array}{l}\text { 1. Encourage } \\
\text { participation in and } \\
\text { arrange educational } \\
\text { courses on AI. } 2 \text {. } \\
\text { Consult with } \\
\text { governmental experts } \\
\text { in other organizations } \\
\text { to develop an initial } \\
\text { understanding on AI. }\end{array}$ & $\begin{array}{l}\text { Estonia, } \\
\text { United } \\
\text { Kingdom, } \\
\text { Serbia }\end{array}$ \\
\hline $\begin{array}{l}\text { Organizational } \\
\text { capacity }\end{array}$ & $\begin{array}{l}\text { The organization } \\
\text { has the } \\
\text { necessary } \\
\text { organizational } \\
\text { capacity to plan } \\
\text { and implement } \\
\text { an AI-based } \\
\text { system }\end{array}$ & $\begin{array}{l}\text { Feasibility } \\
\text { assessment, } \\
\text { implementation } \\
\text { and } \\
\text { organization of } \\
\text { procurement }\end{array}$ & $\begin{array}{l}\text { 1. Develop clear } \\
\text { guidelines that specify } \\
\text { the key challenges and } \\
\text { risks with public } \\
\text { procurement of AI- } \\
\text { based systems. } \\
\text { 2. Provide guidance } \\
\text { and best practices for } \\
\text { AI procurement, for } \\
\text { example by providing } \\
\text { templates or sample } \\
\text { procurements }\end{array}$ & $\begin{array}{l}\text { Estonia, } \\
\text { United } \\
\text { Kingdom, } \\
\text { Netherlands, } \\
\text { Serbia }\end{array}$ \\
\hline $\begin{array}{l}\text { Individual } \\
\text { capacities }\end{array}$ & $\begin{array}{l}\text { The organization } \\
\text { has employees } \\
\text { who possess the } \\
\text { necessary } \\
\text { capacities to } \\
\text { manage, } \\
\text { procure, and/or } \\
\text { implement the } \\
\text { public } \\
\text { procurement of }\end{array}$ & $\begin{array}{l}\text { Feasibility } \\
\text { assessment, } \\
\text { implementation } \\
\text { and } \\
\text { organization of } \\
\text { procurement }\end{array}$ & $\begin{array}{l}\text { 1. Encourage } \\
\text { participation in and } \\
\text { arrange educational } \\
\text { courses on AI. }\end{array}$ & Estonia \\
\hline
\end{tabular}




\begin{tabular}{|l|l|l|l|l|}
\hline & $\begin{array}{l}\text { AI-based } \\
\text { systems }\end{array}$ & & & \\
\hline
\end{tabular}

\section{List of Interviewees}

EE.PS1 - Senior government IT advisor.

EE.PS2 - Ministerial Chief Information Officer.

EE.PS3 - Private sector manager involved in organizing ministerial data dives.

NL.PS1 - Senior ranking official involved with creation of Amsterdam's AI guidelines.

RS.PS1 - Senior ranking governmental advisor on public sector reform.

RS.PS2 - Official involved in the creation of Serbia's AI strategy.

RS.PS3 - Senior official in Prime Minister's office's IT team.

RS.PS4 - Senior official in Prime Minister's office's IT team.

UK.PS1 - Senior consultant in UK's AI Procurement guidelines team. 